\title{
The unbearable lightness of différance: The ethos of deconstruction
}

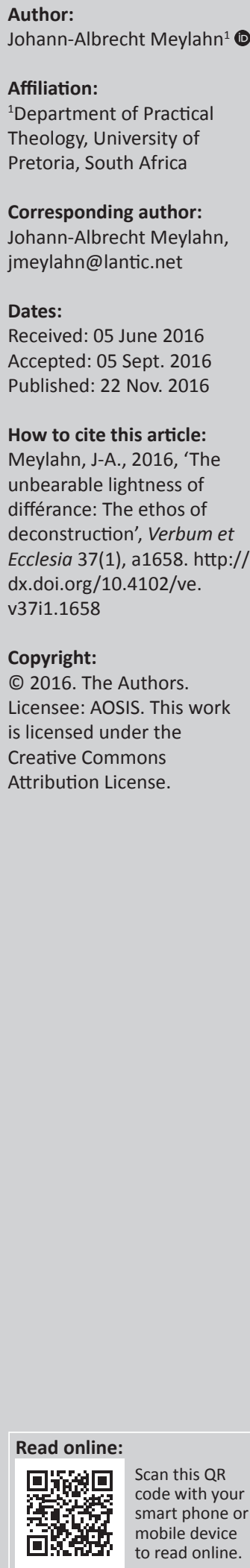

The unbearable lightness of différance is in reference to Milan Kundera's famous book, The unbearable lightness of being. Being is unbearably light, if interpreted as Heidegger did as either the meaning of Being or the truth of Being, yet in Derrida's response to Heidegger he argues that différance is 'older' than the meaning of Being, even older than the truth of Being, and thus one could argue that différance is even lighter than Being and thus even more unbearable. What possibilities does such an unbearable lightness of différance offer to human being-with (Mitsein) in a global village faced with so many socio-economic and environmental challenges? The unbearable lightness could be absolute relativism and particularism as Rawls has interpreted it or it could be the unbearable lightness of auto-deconstruction. The unbearable lightness of différance opens a socio-political space with an ethos of deconstruction and thereby response or ibility towards the other. This lightness of différance can be interpreted as a difficult liberty (difficult liberty as Levinas interprets it) or even an unbearable liberty of infinite broken chains of signifiers and yet a freedom that is held to account (that responds) to the other. This liberty is an infinite responsibility towards the other and therefore infinite responsibility towards justice (diké). Différance is liberty as all there is, is text, but this liberty is not licentiousness of absolute disconnection, but the difficult liberty of being only responsible towards the other. The question this article will grapple with is: what ethical implications can be gathered from this state of being-with, this unbearable lightness of différance in the global village?

Intradisciplinary and/or interdisciplinary implications: Philosophy and philosophy of religion. The article focusses on the conversation between Heidegger and Derrida, with regards to différance and Austrag.

\section{Introduction}

In this article I will argue that there is not only a close proximity but also an important difference ${ }^{1}$ between Heidegger and Derrida concerning Being and différance, but the article will seek to argue that Derrida's différance is 'older' and thus lighter than Being and therefore an even more unbearable lightness. The idea of an unbearable lightness is borrowed from Milan Kundera's book, by the same name, The Unbearable Lightness of Being. In the second part of the article the religious, ethical and social consequences of this unbearable lightness of différance will be explored with regard to Mit-Sein, namely being-together in the global world.

\section{Discussion}

Being and différance have both to do with Heidegger's and Derrida's interpretation of the end or closure of metaphysics. It is in this Lichtung of the closure of metaphysics that the unbearable lightness of différance will be thought. Derrida argued that any attempt to transgress metaphysics will be re-enclosed within metaphysics (Derrida 1981b:13), and thus there is no way beyond metaphysics and therefore he prefers the word closure rather than Heidegger's end. The closure of metaphysics is a moving limit that restores each transgression and transgresses each restoration. It is like the Verendung of completed (vollendeten) metaphysics and this Verendung (closure) is without end as it is infinite and inde-fin-ite. 'That which is caught in the de-limited closure can continue indefinitely' (Derrida 1981b:13).

The difference between the two is to be found not in Derrida's choice of the word 'closure' in opposition to Heidegger's 'end', but rather in what the word closure designates beyond

1.Derrida himself argues that nothing he does would have been possible without Heidegger (Derrida $1982: 22 \mathrm{ff}$ ) Yet, he also seeks to differentiate himself from Heidegger, but in Derridian fashion, which he learnt from Heidegger, from within the text of Heidegger The close connection and even dependence of Derrida's thoughts on Heidegger already becomes apparent in the similarity, or rather semantic proximity, of the words they used. Heidegger introduced the idea of Destruktion and Derrida preferred the term deconstruction, yet the relationship between these two concepts cannot be denied. There are those who argue, for example deconstruction, yet the relationship between these two concepts cannot be denied. There are those who argue, for example
Bennington (1993), that 'what Derrida does' is in part a translation into French of Heidegger's Destruktion. Besides deconstruction and Bennington (1993), that 'what Derrida does' is in part a translation into French of Heidegger's Destruktion. Besides deconstruction and
Destruktion Heidegger's use of the term dif-ference (Austrag) is in close proximity to Derrida's différance. This close proximity of difference and différance becomes clear when reading Heidegger's Kant and the problem of metaphysics (see also Bennington 1993:272). 
Heidegger's Vollendung of metaphysics. It designates an enclosing of metaphysics. Metaphysics is enclosed in a circular process of transgression and restoration and thus encloses whatever is within this circularity of the metaphysical text as there is no outside text (Derrida 1997:158). In Heidegger's thought there seems to be a trace (frühe Spur) of an outside text by which the epochal sendings of Being can be compared and evaluated as some are closer and others further from the Truth of Being. For Derrida there is no such outside text that can arbitrate concerning the epochal sendings of history. Therefore, one can argue that for Heidegger, what is present is still to some degree related to what is represented, even if it is through the medium of language as the house of being. Thus beings (what is present) are still to a degree dominated by the presencing and thus not unbearably light as they are bound by presence.

What Derrida's thoughts challenge is the 'domination of beings' (Derrida 1982:21), the domination of presence which is challenged by différance in that différance solicits this very domination of beings, but in the sense of the Latin sollicitare, which means to shake the whole (Derrida 1982:21). This play of words: différance solicits (calls) beings to come into presence and thus be dominated by presence. Différance calls presence, metaphysics, to its dominion, but it calls it to its dominion in that it lets the whole system tremble. What différance calls forth it also fundamentally questions, but keeping in mind that différance, as such, does not call forth anything. This is another way of speaking of the transgression and restoration - différance restores or recalls what it transgresses and transgresses what it recalls or restores. What is being challenged, therefore, is the determination of Being as presence or as beingness (Derrida 1982:21). Derrida (1982) argues that such a challenge would not be possible if the difference between Being and beings is not broached:

\footnotetext{
... différance is not. It is not a present being, however excellent, unique, principal, or transcendent. It governs nothing, reigns over nothing, and nowhere exercises any authority. It is not announced by any capital letter. Not only is there no kingdom of différance, but différance instigates the subversion of every kingdom. Which makes it obviously threatening and infallibly dreaded by everything within us that desires a kingdom, the past or future presence of a kingdom. And it is always in the name of a kingdom that one may reproach différance with wishing to reign, believing that one sees it aggrandize itself with a capital letter. (pp. 21-22)
}

From the above quote it is clear that différance is not Being, and it is not the truth or the meaning of Being and thus it cannot be the ontico-ontological difference, although they are in very close proximity. Hoy argues that Derrida thinks that Heidegger is still committed to an ultimate metaphysical reality (Hoy 1979:225), and according to him, this would be a misunderstanding of Heidegger's understanding of the 'truth of Being'. For Heidegger, according to Hoy, "'Being" is merely a metalinguistic notion resulting from a transcendental deduction based on the need for something to which language could refer' (Hoy 1979:232). In taking Hoy's interpretation of Heidegger seriously the difference between the two seems to disappear, and therefore one can argue that Derrida and Heidegger are not that far apart or that the difference between them needs to be sought elsewhere.

Derrida was very aware of his proximity to Heidegger. When Derrida was asked the question, whether différance can be equated with the ontico-ontological difference, he responded that it is difficult to answer this question (Derrida 1982:22) because différance, in a certain sense, is exactly the historical and epochal unfolding of Being, or the ontological difference (Derrida 1982:22). Yet in another sense it is not. To understand this fine difference, Derrida turns to Heidegger's interpretation of Nietzsche and argues that Nietzsche actually went further than Heidegger in liberating the sign from a transcendental signified (Derrida 1997:19) and the unbearable lightness of being, and it is here that the difference between the two becomes important. The difference can be stated bluntly by arguing that différance has 'priority' over the onticoontological difference in the sense that one can say that Heidegger's thinking of the meaning and the truth of Being are determinations of différance as the ontico-ontological difference is an intrametaphysical effect of différance (Derrida 1982:22). Thus the unfolding of différance is not merely the truth or meaning of Being nor the epochality of Being, but it is 'older' than the truth or meaning of Being. Derrida suggests that one needs to think of the truth of Being and the epochality of Being as an epoch of the diapherein (Derrida 1982:22). For this reason it would not be correct to even call this an epoch, as epochality would still fall within the idea of the history of Being. Différance 'is' older than the ontico-ontological difference and the truth of Being (Derrida 1982:22). Being does not have meaning or truth as such, but its meaning and truth are revealed in the dissimulation of itself in beings. In this sense, différance is older than the truth of Being and older than the ontico-ontological difference, and then 'its age' can be called the play of the trace. A play of the trace which no longer belongs to the horizon of Being, 'but whose play transports and encloses the meaning of Being: the play of the trace, or the différance, which has no meaning and is not' (Derrida 1982:22). Having said this, Derrida argues further that this does not mean that one can do away with Heidegger's ontological difference or the thinking of the truth of Being. On the contrary, he argues that one needs to stay within this thinking (Derrida 1982:22-23).

The task according to Derrida (1982) is to permit to appear or disappear:

the trace of what exceeds the truth of Being. The trace (of that) which can never be presented, the trace which itself can never be presented: that is, appear and manifest itself, as such, in its phenomenon. (p. 23)

This sounds very similar to Being in Heidegger's thoughts. Yet, Derrida's trace cannot be equated with Being, contrary to what Bennington argues (Bennington 1993:273-274). Derrida turns to a re-reading of Heidegger's reading of Nietzsche as he argues that Nietzsche more than any other has liberated the sign 'from its dependence or derivation with respect to the logos and the related concept of truth or the primary signified, 
in whatever sense that is understood' (Derrida 1997:19). He argues that Heideggerian thought returns so as to reinstate a form of logos or a primum signatum: the transcendental signified (Derrida 1997:20) that Nietzsche had fundamentally questioned. It would be a great injustice to argue that Heidegger reinstated a primum signatum in the classical metaphysical sense. Heidegger says in his Postface to Was ist Metaphysik?, 'Thought obeying the Voice of Being ...' (Heidegger 1960:46), which becomes the last resource of the sign. This quote certainly refers to the earlier Heidegger and the later Heidegger would probably not make such a statement, especially once he started writing Being under erasure. Derrida realises this and he says that Heidegger's sense of Being is never simply and rigorously a 'signified' (Derrida 1997:22), but he continues his argument and says that even if Heidegger writes Being under erasure, the presence of a transcendental signified might be effaced, but it still remains legible (Derrida 1997:23). The transcendental signified is destroyed, but it still makes possible the very idea of a sign. 'In as much as it de-limits onto-theology, the metaphysics of presence and logocentrism, this last writing is also the first writing' (Derrida 1997:23). To distinguish their paths is very difficult, but Derrida (1997) agrees with this as he argues:

To come to recognize, not within but on the horizon of the Heideggerian paths, and yet in them, that the sense of being is not a transcendental or trans-epochal signified. (p. 23)

Derrida engages with Heidegger in numerous texts. In The Double Session Derrida reflects on Heidegger's interpretation of mimesis (Derrida 1981a:198). Derrida, reflecting on Heidegger's interpretation of language as showing rather than signifying, brings in the idea of a stage as the space (the language) that shows rather than signifies. A stage can be interpreted as a presence which does not present itself as it disappears in the act of allowing to appear, and this is exactly how language works as well (Derrida 1981a:343ff.). Derrida further explores the idea of the stage showing, but it is always believed to also represent, and yet using the play 'Pierrot Murderer of his wife' challenges the idea of representation, but what it shows is an effect of the structure of the fold (Derrida 1981a:343ff.).

This will be further explored by returning to Derrida's interpretation of Heidegger's The Anaximander Fragment in order to continue to argue for both the proximity and the difference between his thought and that of Heidegger (Derrida 1982:23). Heidegger in this text recalls that the forgetting of Being is to forget the difference between Being and beings. The matter of Being (Sache des Seins) is to be the Being of beings (Derrida 1982:23). The grammatical form of this enigmatic, ambiguous genitive indicates the following:

- a genesis (Genesis)

- the emergence (Herkunft) of what is present from presencing (des Anwesenden aus dem Anwesen) (Derrida 1982:23)

- yet the essence (Wesen) of this emergence remains concealed (Verborgen) along with the essence of the two other words (Present and presencing).
The relationship between presencing and present is not thought as it was necessarily believed that presencing becomes from itself something present. The ontological difference is the difference between presencing and present (Anwesen und Anwesenden). Derrida argues that what Heidegger is advancing is that the difference between Being and beings, Anwesen and Anwesenden, has been forgotten and has disappeared without a trace. It is the very trace of difference that has been submerged (Derrida 1982:23). Yet différance 'is' neither presence nor absence, but other to both, and thus one can say that différance traces this forgetting of the difference between Being and beings, but 'itself' is beyond presence and absence and thus one will have to speak of the trace of the trace if one speaks of différance. The difference between Being and beings, presence and presencing, is derivative of différance (Derrida 1997:23).

It is the 'essence' of Being to veil itself, as it unveils itself in the presencing of what is present, but in what is present it has disappeared (concealed itself). This sounds very similar to Derrida, and yet the difference is that for Heidegger there remains the idea of an early trace (frühe Spur). Derrida developed his understanding of a trace in conversation with Levinas (Derrida 1982:12.21). The difference between Derrida's trace and Heidegger's Spur is a very subtle difference. The difference between Heidegger's interpretation of the Spur and Derrida's trace can be understood if one understands Heidegger's view of authentic language. Heidegger, in The Question of Being, speaks of a meaningfullness of authentic language (Heidegger 1958:105). This plenitude (fullness) is not an historical accumulation, but a play of unfolding for Heidegger. 'A play which, the more richly it unfolds, the more strictly it is bound by the hidden rules' (Heidegger 1958:105). Yet this play is always commanded by an origin it can never fully name (frühe Spur).

Derrida's trace is a play that is more playful than this play of the frühe Spur in Heidegger (Riddel 1976:587). Derrida's play is without an origin outside the play - all one has is the text as there is no outside text. This is a play more unbearable that the unbearable lightness of Being.

The early trace (frühe Spur) is not a present, but a simulacrum (supplement) of a presence, and therefore it has no place as it dislocates itself, replaces itself and refers itself: it is under erasure. The present is all there is, but the present is a sign or a trace. As has been discussed, it is a sign of a sign and therefore the present is a trace of a trace (Derrida 1982:24).

This is how the text of metaphysics is to be comprehended. It is comprehended on the basis of this forgetting of the trace, forgetting of the difference between present and presencing and thus Being and beings. What is present is taken to be the highest present, thus totally forgetting the presencing, and that what is (present) is only a trace made possible by the forgetting of presencing. Derrida's closure of metaphysics is not its end because the text is 'still legible; and to be read' (Derrida 1982:24). The metaphysical text is marked in its 
interior by the multiple furrow of its margin, thus producing at the same time the monument and the mirage of the trace, the trace simultaneously traced and erased, simultaneously living and dead (Derrida 1982:24). Heidegger connects the trace to the essence of Being and the oblivion of Being, and Derrida challenges this unilateral connection.

Where Derrida does critique Heidegger is with regard to the unilateralism of Heidegger's claim that there is a 'sending of Being from the Greeks through epochs of increasing oblivion, which is gathered into the destiny or destination of Being at the end of philosophy' (Critchley 1999:84). Derrida challenges the inherent eschatology and teleology and compares it to a postal idea, whilst wondering if this sending of Being is not threatened by dissention or dissemination, which would divert the destining and gathering of Being and thus deconstruct Heidegger's text:

To the original 'Envoi' of Being, Derrida opposes a plurality of 'envois', inassemblable singularities, postcards, which cannot be gathered into a unity history (Geschichte) of the destining (Geschick) of Being. (Critchley 1999:85)

Thus, for Derrida, the eschatology of Being, the closure of metaphysics or the End of Philosophy is not to arrive at its end (teleology), but is continually breached, interrupted by a postal différance. This différance is older (Derrida 1982:22) than the ontological difference and therefore cannot be represented as a unitary history. Derrida is heading towards a thought of multiple sendings that would have the form, neither of presence nor of representation, but rather of a plurality of sendings (postcards, voices, events) that would construct a structure that is incapable of being structured:

Sendings would be an infinite web or general text of singularities, of events that would be pre-ontological and incapable of being gathered into Being or represented as a unitary epoch possessing a sender, an address, and a destination. (Critchley 1999:86)

Later on in Derrida's work he seldom uses the word closure and seems to replace it with other words, such as limite or even wholly other (Critchley 1999:87):

The problem of closure does not enclose the space of a unitary history and foreclose the possibility of transgression but rather traces the double necessity and double impossibility of both belonging to a history whose closure can be delimited and not belonging to a history whose closure we are unable to leave. There is no exit within a repetition of the tradition, and there is no exist without that repetition. It is only through a ceaseless and massive repetition of Heidegger's thought that an ellipsis arises from which the other to Heidegger's thinking may be approached. (p. 88)

Yet this kind of reading of texts Heidegger himself proposed when he argued that it is only through the power of an illuminative idea that interpretation can risk that which is always audacious, namely to entrust oneself to the secret élan of a work and only then, via this élan, to get through to the unsaid of the text and find an expression for it (Heidegger 1962:207).
Derrida challenges the unitary history of metaphysics from the Greeks to today, yet this challenge can only be possible from within such a tradition. The possibility of numerous sendings can only be thought from the expectation of a unitary sending. What is outside the text? Or how to conceive what is outside a text? 'That which is more or less than a text's own, proper margin' (Derrida 1982:25). The trace is both sheltered (monument) and dissimulated in the various names of Western metaphysics.

Yet, différance remains a metaphysical name if it names the difference between present and presencing, Being and beings (Derrida 1982:26), but what Derrida has been arguing in this essay is that différance is 'older' than Being itself. Does this 'older' than Being have a name in the Western metaphysical language? It has no name, because a name has not yet been found in the hope that one day a name will be found, but it has no name, because to find a name one would have to move outside the text and there is no outside text with which to give a name to différance which is 'older' than Being and thus unbearably light. This unnameable is not some kind of ineffable Being! The unnameableness of différance does not bring it into proximity with the unnameable God for example. The unnameable of différance is the play that makes names possible; thus God would be a nominal effect of différance.

What one can conclude is that there never was and never will be a unique word or a master name as even the non-word or non-concept or non-name, différance, is itself caught in the nominal effects it affects and determines. This is the critique of metaphysical God-talk where God cannot be a master name or master word. Différance does not refer to an origin nor to an end, but it refers, if it refers to anything, to the play in and of the text in which one always and already is. Derrida says: "There is nothing kerygmatic about this "word", provided that one perceives its decapita(liza)tion. And that one puts into question the name of the name' (Derrida 1982:27).

This loss of origin or eschaton is not something that one should mourn, but it is something that one can affirm - both the play and the openness of an indefinable open eschatology offering hospitality to the other that is always still to come. This affirmation is an openness towards the Other, and thus hope - a Heideggerian hope (Derrida 1982:27). Heidegger says that one would have to search for the single unique word in order to name the essential nature of Being. Thus any thoughtful attempt at addressing Being is daring, but such daring is not impossible 'since Being speaks always and everywhere throughout language' (Heidegger 1975:52). This same hope is inspired by the inscription in the 'simulated' affirmation of différance. It bears (on) each member of this sentence: 'Being/speaks/always and everywhere/throughout/ language' (Derrida 1982:27).

This unbearable lightness of différance is so unbearable, because of the play of the trace, that it is only human to seek to arrest this play by assimilating différance into a narrative that makes it bearable. This is what François Laruelle (2010) argues 
Derrida did by doing exactly what Derrida criticises Heidegger of doing: seeking to escape the unbearable lightness of différance by embedding this lightness within another narrative - not Heidegger's grand historical narrative of the Sending of Being, but the narrative of deconstruction and the dream of justice and democracy always still to come. This criticism, or should I rather say this conversation between Laruelle and Derrida, forms a fine line between the two. Laruelle accuses Derrida of a dualism or rather of being a philosopher of difference, where in the end there is again a sense of identity of differences (Laruelle 2010), specifically, according to Laruelle Derrida's idea of deconstruction and his idea of the messianism without Messiah. Yet, Derrida does not have a system or metanarrative of Deconstruction with a capital $\mathrm{D}$, but if anything it is not a method at all, but an autodeconstruction (see Critchley 1999:22; Derrida 1986:41) and certainly is not a system or metanarrative, and yet it is possible to understand why Laruelle argues that Derrida's deconstruction can form the basis of a new kind of metanarrative to arrest the unbearable play, lightness, of différance. Thus one could say that Laruelle argues that Derrida makes the unbearable lightness of différance bearable, by placing the unbearable play into the narrative of the dream of democracy and justice still to come. Although Derrida's work on democracy and justice to come are only developed later and therefore could not have been part of Laruelle's critique of Derrida. This is the only way that I can understand Laruelle's critique.

This unbearable lightness of différance is a difficult liberty as in a sense it is an absolute freedom; the absolute freedom of radical immanence: there is no outside text; there is nothing to which one can abdicate one's responsibility to. This freedom (liberty) is difficult and unbearable and against human nature to remain in a state of unbearable liberty or vulnerability, and therefore there is always the tendency to seek to overcome it by placing it into a grand narrative of justice and democracy always still to come as if one could write Democracy and Justice with capital letters.

What would it be if it is not placed into such a narrative? What if one remains in this unbearable lightness of différance and justice and democracy to come without capital letters, that is without knowing what kind of democracy and what kind of justice is to come? In the unbearable lightness of différance, democracy and justice can in no way be a kind of Machenschaft where you can construct or manage Democracy and Justice, but rather where the ethos for Mitsein is an active Gelassenheit. It is active in the sense of awareness and recognition of our vulnerability and longing or desiring for the unknown future and thereby being continually estranged (autodeconstructed) by that unknown future: what is still to come. It is an ethos of active longing and desiring for future justice and a future democracy, but without knowing what kind of democracy and justice. An ethos for Mitsein where place is given not to the Other, as Laruelle argues that the Other and the One are a unilateral duality (Laruelle 1999:143); facing not the Other, but as unilateral duality facing the future (Laruelle 2011:254) and thus, with the one and the Other, place is given to the future.

Where all there is, is text, no Other (as the Other is also already text, as it is thought and as thought it is text) then text and
Other, as text, unilaterally face the future. In that future there is justice and democracy to come, but a justice and democracy that is beyond any conditioning, absolutely unconditional, given as gift without givenness and thus as a gift of divine violence (violence without a specific end in mind) (see Žižek 2008:463ff.), and therefore what is necessary is an active Gelassenheit: Gelassenheit to receive that gift and active in the sense of being open to receive it, to desire it or to be desired by it and thus to become continually a stranger subject ${ }^{2}$ or a holy fool (see Meylahn 2011:322f.; Thomas 2009). A holy fool who is totally exposed or enucleated by the future still to come thus questioning and exposing all that is as being foolish.

One is not held to account for or to the other, but the one and the Other together are held in awe of the future and the divine violence of that future breaking in to what is, and opening what is, exposing what is, estranging what is by what is to come: absolute future, and in that sense the future holds a promise of justice and democracy by autodeconstructing what is, but a justice and democracy beyond our reasoning - on the contrary, a justice and democracy that would disturb our reasoning and calculability as it would be beyond calculability, maybe like some of the parables of the kingdom to come (Lk 15:1-32; Lk 15:15; Mt 20:1-16): a justice beyond calculability.

\section{Conclusion}

This leaves one with absolute responsibility as there is no Other to whom one can abdicate this responsibility. In that sense it is an absolute responsibility not responding to something or someone, nor being responsible to something or someone beyond the immanence of the text, but responsible and responding to what is given in the unbearable lightness of being given without givenness: différance, infinitely disturbed by the unknown future. Yet, together with this absolute responsibility is the vulnerability of exposedness to the unknown future and the auto-deconstruction of what is. An auto-deconstruction as an exposedness or enucleation to and by the future, where space is continually (auto) being made for the other still to come and in that sense justice (diké) and democracy, but a justice and democracy beyond our control and beyond calculability and Machenschaft: a divine justice and divine democracy. This leaves one with an ethos of expectancy, of desiring the unknown future that is beyond our control and a humble recognition of the vulnerability of all that is, as all that faces the unknown future and the justice and democracy to come, beyond our ability to influence and determine that which is to come - the unbearable lightness and the unbearable weight of différance.

\section{Acknowledgements Competing interests}

The author declares that he has no financial or personal relationships which may have inappropriately influenced him in writing this article.

2.'The non-philosophical subject distinguishes itself form the subject which is philosophical in type. It is a purely transcendental subject, distinct from the real Ego, philosophical in type. It is a purely transcendental subject, distinct from the real Ego,
turned toward the World to which it is a stranger and towards which it turns itself as stranger' (Laruelle 1999:146). 


\section{References}

Bennington, G., 1993, 'Derridabase', in G. Bennington \& J. Derrida (eds.), Jacques Derrida, transl. G. Bennington, University of Chicago, Chicago, IL.

Critchley, S., 1999, The ethics of deconstruction: Derrida and Levinas, 2nd edn. Edinburgh University Press, Edinburgh.

Derrida, J., 1981a, 'The double session', in Dissemination, transl. B. Johnson, pp. 175-286, University of Chicago Press, Chicago, IL.

Derrida, J., 1981b, Positions, transl. A. Bass, Athlone Press, London.

Derrida, J., 1982, Margins of philiosophy, transl. A. Bass, Harvester, Brighton.

Derrida, J., 1986, Memoires for Paul de Man, Columbia University Press, New York.

Derrida, J., 1995, 'Khōra', in T. Dutoit (ed.), On the name, transl. I. McLeod, pp. 89-127, Stanford University Press, Stanford, CA.

Derrida, J., 1997, Of grammatology, transl. G.C. Spivak, John Hopkins Press, Baltimore, MD.

Heidegger, M., 1958, The question of being, transl. W. Kluback \& J.T. Wilde, College and University Press, New Haven, CT.

Heidegger, M., 1960, Was ist Metaphysik?, Klostermann, Frankfurt am Main.

Heidegger, M., 1962, Kant and the problem of metaphysics, transl. J.S. Churchill, Indiana University Press, Bloomington, IL.
Heidegger, M., 1975, Early Greek thinking, transl. D. Krell, Harper \& Row, New York.

Hoy, D.C., 1979, 'Forgetting the text: Derrida's critique of Heidegger', Boundary 2. The problems of Reading in Contemporary American Criticism: A Symposium 8(1), 223-236. http://dx.doi.org/10.2307/303149

Laruelle, F., 1999, 'A summary of non-philosophy', Pli: The Warwick Journal of Philosophy 8, 138-148.

Laruelle, F., 2010, Philosophies of difference: A critical introduction to non-philosophy, transl. R. Gangle, Continuum, New York, Kindle edition.

Laruelle, F., 2011, 'The generic as predicate and constant: Non-philosophy and materialism', in L. Bryant, N. Srnicek \& G. Harman (eds.), The speculative turn: Continental materialism and realism, pp. 237-260, re.press, Melbourne.

Meylahn, J.A., 2011, 'The limits and possibilities of postmetaphysical God-talk: A conversation between Heidegger, Levinas and Derrida', Unpublished PhD dissertation, Vrije Universiteit Amsterdam, Amsterdam.

Riddel, J.N., 1976, 'From Heidegger to Derrida to chance: Doubling and (poetic) language', Boundary 2, Martin Heidegger and Literature 4(2), 539-592. http://dx.doi.org/10.2307/302154

Thomas, A., 2009, The holy fools: A theological inquiry, Unpublished PhD thesis, University of Nottingham, Nottingham.

Žižek, S., 2008, In defense of lost causes, Verso, London. 